\title{
An investigation on of job satisfaction in accounting and auditing institutions of commercial companies
}

\author{
Saeid Baseri*
}

Department of Accounting \& Management, Kashan Branch, Islamic Azad University, Kashan, Iran

\begin{tabular}{l}
\hline C H R O N I C L E \\
\hline Article history: \\
Received September 28, 2012 \\
Received in revised format \\
19 November 2012 \\
Accepted 20 November 2012 \\
Available online \\
November 272012 \\
\hline Keywords: \\
Job satisfaction \\
Motivation \\
Job change \\
Job security \\
Auditing work conditions \\
\end{tabular}

\section{A B S T R A C T}

\begin{abstract}
Experiences in recent years about industrial and official system of the Iran and other countries and successful organizations show that human resource plays an important and principal role in economic and social development of countries \& organization. Therefore, fundamental investment is considered and principle utilization of it with the increase in productivity level is one of the certain rules in development and advance of a country or organization. The main objective of this study is to examine the job satisfaction of auditors of audit organizations in comparison to accountants in Business enterprise. In addition, the author tries to analyze the effective factors on job satisfaction in two groups to point to essential guidelines and decrease the job quit in this part of society and increase the efficiency of human resource, even very little . Results obtained from the study hypothesis show that range of dissatisfaction among auditors is more than accountants are.
\end{abstract}

(C) 2013 Growing Science Ltd. All rights reserved.

\section{Introduction}

Human resource plays an important role on technology development and people always try to optimally use resources. According to Robbins and Judge (2010) when there is a shortage in fulfilling human resources' needs, people will less likely to work, efficiently. Therefore, it should be recognized that no work in society and especially in an organization is more important than leading and growth of human beings and technology cannot move without their satisfaction. In view point of Specter, job satisfaction is the most common variable of research in organizational behavior (Huff, 2000). Job satisfaction is a set of emotions and beliefs that people have about their current job (George \& Gareth, 1999). As a result, attention to internal and external employees' requirements and creating the background on grow or flourish the creativity and hidden skills of people will lead to increase the efficiency of the organization and interest of people to work and their faith or respect to the organization.

*Corresponding author

E-mail addresses: s.baseri@iaukashan.ac.ir (S. Baseri) 
In spite of individual and social needs, if people or employees are not supported well or responded, properly, their faith or commitment to the organization will decrease and gradually they may leave the organizations (Homan, 2002). In other words, if appropriate work conditions are not provided out of the organization, trend and interest of workers to work will decrease and lead to low efficiency of organization. Therefore, there is a need to study on how to take care of employees for the success of organizations. This issue is considered in auditing institutions and business companies and the focus of this paper is more on accountants and auditors in terms of their duties and their job sensitivity.

In this paper, we analyze positive and negative factors influencing on job satisfaction of the two groups and discuss differences.

\section{Theoretic principles and background of the study}

Management accounting literature discusses about the job satisfaction in many organizations and analyzes different factors leading to employees' dissatisfaction. Deen et al. (1988) evaluated the decrease of job satisfaction in auditors more than accountants, by studying the accountants of an industrial company and auditors work in eight great auditing institutions.

Albrecht \& colleagues (1981) studied the way to face professional employees of 25 auditing intuitions and concluded that in spite of partners who had full satisfaction of conditions, auditors, supervisors and managers did not have job satisfaction.

Eilatealamdari (1988) studied different effective factors on job satisfaction among auditors and showed that salary was the most influencing factor on job satisfaction. According to Lawson \& Shen (1998), there is a need for continuous improvement on human's requirements and meeting their needs to improve firms' performance. This also helps organizations learn more on how empower their organizations. Those people whose needs are met in organization will tend to be more strong and satisfied with their work when they have a given responsibility to do their duties and to solve the problems. These people are normally given a set of partial hard duties and their strong interests to see their performance are evaluated. In addition, they are not interested to be evaluated by money for themselves, but they enjoy money as a symbol for succeed (Parker \& Chusmir, 1992).

Shekarriz (1991) recognizes Salary, job security, job persistence, good work conditions, tools to advance and promote and human relations as the most influencing factors on job satisfaction. The higher is the level of responsibility, independence and variation in job, the better is the efficiency. However, the more individuals are in higher levels in terms of education, abilities, etc., the required levels of these properties are and should be higher to obtain happiness and satisfaction (Zandipor, 1990).

There are some evidence indicating that there is a moderate and consistent relationship between job satisfaction and absence of employees from their work. According to Parker and Chusmir (1992), awareness and sensitivity to organizational, employees' requirements and providing a good field of their support is very critical, because it causes the work programs to be carried out more flexibly and profitably (Mohammadzade \& Mehrozhan, 1996).

Khodaei Valahzaghard et al. (2012) performed an empirical study on the effects of human resource supporting strategies on job satisfaction. They investigated the effects of related services to support employee to reach job satisfaction and employee activities in one of Iranian banks. The results showed that employees were relatively satisfied from the benefit package of the bank and they were relatively happy on working for such organization.

\section{Research method}

The main objective of this study is to evaluate the job satisfaction of accountants and auditors and to compare them. Therefore, this study is descriptive and its method is considered as field method. 


\subsection{Hypothesis of the study}

Rate of job satisfaction in auditors is lower than accountants.

In addition, this study compares job satisfaction between the two groups of auditors and accountants in terms of different aspects of job satisfaction including kind and nature of the work, supervisor inspection, colleagues, promotion, payment and benefits, which are among all main components of this study.

\subsection{Statistical society and subjects}

Statistical society of the study, on one hand contains all employed auditors in auditing institutions members of formal accountant association, including levels: "auditor, supervisor auditor, supervisor, superior supervisor and manager or partner of the institution". On the other hand, it contains all employed accountants in accepted companies of Tehran stock exchange including different items of financial manager, head of financial accounting, head of industrial accounting and employees of accounting departments with, at least, a three-year of job experience. According to the data of statistical department of formal accountant association and Tehran stock exchange, number of auditors are 3000 and accountants are 3500. Of these people, 133 of accountants and 152 of assistants were selected based on a random sampling technique as the subjects and a questionnaire is sent to them. Table 1 shows some of the questionnaires' components.

Table 1

Number of sent and back questionnaires

\begin{tabular}{ccccc}
\hline Row & Explain & Sent & Received & Back percent \\
\hline 1 & accountants & 133 & 93 & $69.9 \%$ \\
2 & auditors & 152 & 123 & $80.9 \%$ \\
\hline & total & 285 & 216 & $75.8 \%$ \\
\hline
\end{tabular}

\subsection{Measurement tools}

According to the aims of the study, the best way to collect data, is to use questionnaire (Bazargan \& Sarmad, 2001). To do this, Mine Suta Questionnaire (MSQ) of job satisfaction was used. In order to score the questions, Porter method was used in terms of difference between individual expectations from job and what the individual receives from his/her job. Since the possibility of mentioned validation is different, math hope of these validations are estimated as follow:

Table 2

Difference of the validity of questions options

\begin{tabular}{lcccccc}
\hline \multicolumn{2}{l}{ What must be } & Very little & Little & Medium & Much & \multicolumn{2}{c}{ Very much } \\
& 1 & 2 & 3 & 4 & 5 \\
\hline Very little & 1 & 0 & 1 & 2 & 3 & 3 \\
Little & 2 & 1 & 0 & 1 & 2 & 2 \\
Medium & 3 & 2 & 1 & 0 & 1 & 1 \\
Much & 4 & 3 & 2 & 1 & 0 & 0 \\
\hline Very much 5 & 4 & 3 & 2 & 1 & \\
\hline
\end{tabular}

Number of 1.60 is delicate the boundary between satisfaction \& dissatisfaction. In order to assure the data obtained from analysis of the questionnaire, valid ability rate of the questionnaire was obtained using SPSS software test and Thornback was equal to 0.7802 . 


\subsection{Study findings}

Study and determination of job satisfaction and comparison of job satisfaction between accountants and auditors are of the main purposes of this study and in this section data related to the findings are as follow.

Table 3

What hope of answer?

\begin{tabular}{cccc}
\hline Answer value & Answer probably & Probably percent & $\mu$ \\
\hline 0 & 5 & $20 \%$ & 0 \\
1 & 8 & $32 \%$ & 0.32 \\
2 & 6 & $24 \%$ & 0.48 \\
3 & 4 & $16 \%$ & 0.48 \\
4 & 2 & $8 \%$ & 0.32 \\
total & 25 & $100 \%$ & 1.60 \\
\hline
\end{tabular}

Determination of job satisfaction was the first purpose of this study and the statistical properties related to it are provided in table 4.

Table 4

Statistical properties of job satisfaction and its different aspects

\begin{tabular}{|c|c|c|c|c|}
\hline Explain & group & $\mathrm{N}$ & Mean & Std. Deviation \\
\hline \multirow[t]{3}{*}{ Type \& Nature of work } & accountants & 6 & 1.0533 & .32389 \\
\hline & auditors & 6 & 1.3317 & .72240 \\
\hline & Total & 12 & 1.1925 & .55319 \\
\hline \multirow[t]{3}{*}{ Supervision } & accountants & 9 & 1.3211 & .19669 \\
\hline & auditors & 9 & 1.5600 & .24119 \\
\hline & Total & 18 & 1.4406 & .24635 \\
\hline \multirow[t]{3}{*}{ Colleagues } & accountants & 5 & 1.2100 & .22192 \\
\hline & auditors & 5 & 1.4380 & .33147 \\
\hline & Total & 10 & 1.3240 & .29182 \\
\hline \multirow[t]{3}{*}{ Promotion \& Advance } & accountants & 8 & 1.3988 & .26221 \\
\hline & auditors & 8 & 1.3500 & .31039 \\
\hline & Total & 16 & 1.3744 & .27871 \\
\hline \multirow[t]{3}{*}{ Salary } & accountants & 4 & 1.2975 & .23950 \\
\hline & auditors & 4 & 1.8250 & .19502 \\
\hline & Total & 8 & 1.5612 & .34696 \\
\hline \multirow[t]{3}{*}{ Total } & accountants & 32 & 1.2700 & .26294 \\
\hline & auditors & 32 & 1.4788 & .40610 \\
\hline & Total & 64 & 1.3744 & .35529 \\
\hline
\end{tabular}

Findings of this study show that average of job satisfaction in subjects of auditors is $1.48(\mathrm{SD}=0.41)$ and is $1.227(\mathrm{SD}=0.26)$ in subjects of accountants.

These findings show a higher level of satisfaction for accountants. It should be noted that maximum score of job dissatisfaction equals 4 .

Table 5

Test statistic in terms of different aspects of Job satisfaction

\begin{tabular}{clcc}
\hline Row & Description & $\mathrm{t}$ & sig \\
\hline 1 & Type \& Nature of work & -0.861 & 0.409 \\
2 & Supervision & -2.303 & 0.035 \\
3 & Colleagues & -1.278 & 0.237 \\
4 & Promotion \& Advance & 0.339 & 0.739 \\
5 & Salary & -3.416 & 0.014 \\
& & -2.44 & 0.018 \\
\hline
\end{tabular}


In studying the different aspects of job satisfaction (Table 5), job satisfaction rate of accountants in terms of superior supervisor and salary or benefits is more than auditors, meaningfully (with an assurance level of 5\%)

\section{Conclusion \& discussion}

Descriptive studies of the findings show that the average of job satisfaction of accountants is in higher level than auditors is, and in terms of payment and benefits, this difference is more significant and auditors have less satisfaction. As it is shown, since one of the main needs of human is material needs, according to the theory of hierarchical of Mazlow needs, this need can be discussed as the infrastructure of other requirements. Hence attention to it is critical for responsibilities and increase of satisfaction in this group and following it, decrease of human source quit from auditing to accounting, can be promoted by positive perspective towards payment and benefits of auditing and also improvement of perspective in superior supervisors. Generally, from this study findings and regarding to the study base, it is realized that due to undesired results of job dissatisfaction, planners and partners of financial auditing institutes should think of increasing job satisfaction level of their employees. As we have observed from the results of this survey, job position and salary were accounted to be the most important factors influencing job satisfaction among auditors who were working for Iranian firms. Therefore, it is suggested that auditors are encouraged by offering higher level of job positions. It is also recommended to increase auditors' salaries along with job promotions to increase their relative performance.

\section{Acknowledgment}

The authors would like to thank the anonymous referees for constructive comments on earlier version of this paper.

\section{References}

Albretch, W. S., Brown S. W. \& Field, D. R. (1981). Towards Increase job satisfaction of practicing CPAs. Journal of Accountancy, (August), 61-66.

Bazargan, A., \& Sarmad, Z. (2001). Behavioral Science Research method. Tehran. Agah publication. 141 (In Persian).

Dean, R.A., Ferris, K.R., \& Konstans, C. (1988). Occupational reality shock and organizational commitment: Evidence from the accounting profession. Accounting, Organizations and Society, $13,235-250$.

Eilatealamdari, R. (1988). Factors Review of Effective on Auditors Job Satisfaction of in Iran Audit Association. Masters' thesis, 126 (In Persian).

George J. M. \& Gareth, J. (1999). Organizational Behavior Understanding and managing U.S.A., New York, Addison Wesley, 74.

Homan, H. (2002). Preparation and construction of standard measures of job Satisfaction. Center of government management education, Tehran, 72 (In Persian).

Huff, J. W. (2000). Application of attitude strength to job satisfaction. The moderating role of attitude strength in the prediction of organizational outcomes from job satisfaction. Unpublished doctoral dissertation, Northern Illinois University.

Khodaei Valahzaghard, M., Afzali, F., \& Khodaei Valahzaghard, S. (2012). An empirical study on the effects of human resource supporting strategies on job satisfaction. Management Science Letters, 2(5), 1535-1542.

Lawson, R.B., \& Shen, Z. (1998). Organisational psychology: Foundation and applications. New York, NY: Oxford University Press.

Loren, M. \& Rosenberg, J. (1991). Workforce America! Homewood IL: Richard. D. Irwin, 116.

Mohammadzade, A., \& Mehrozhan, A. (1996). Contingency view of organizational behavior. Tabatabaii University publication. 280 (In Persian). 
Parker, B., \& Chusmir, L. H. (1992). Development \& validation of a life- success measures scale. Psychology Reports, 70(1), 627-637.

Robbins, S.P. \& Judge, T.A. (2010). Organizational Behavior. Prentice Hall; 14th ed.

Shekarriz, H. (1991). Industrial and Organizational psychology. Tehran. Sorosh publication, 236332.

Zandipor, A. (1990). Assessment and Career Planning. 209. 